\title{
Agronomic characteristics and chemical composition of Gliricidia sepium grown under different residual heights in different seasons
}

\author{
Shirlenne F. Silva ${ }^{1}$, Maria S. de S. Carneiroํ, Ricardo L. Edvan², Elzânia \\ S. Pereira ${ }^{1}$, Luiz B. de Morais. Neto ${ }^{3}$, Andréa P. Pinto ${ }^{1}$ and Danilo de A. \\ Camilo ${ }^{1}$ \\ ${ }^{1}$ Federal University of Ceará, Department of Zootecnia. Fortaleza city, Ceará State, Postal code, \\ 60020181, Brazil. \\ ${ }^{2}$ Federal University of Piauí, Department of Zootecnia. Bom Jesus city, Piauí State, Postal code, \\ 6490000, Brazil. \\ ${ }^{3}$ Animal Nutrition Company Integral Mix. Fortaleza city, Ceará State, Postal code, 60871680, Brazil.
}

\begin{abstract}
S.F. Silva, M.S. Carneiro, R.L. Edvan, E.S. Pereira, L.B. de Morais. Neto, A.P. Pinto, and D. de A. Camilo. 2015. Agronomic characteristics and chemical composition of Gliricidia sepium grown under different residual heights in different seasons. Cien. Inv. Agr. 44(1): 35-42. This research was conducted to evaluate the agronomic characteristics and chemical composition of Gliricidia sepium (Jacq.) Steud grown under different residual heights in different seasons. The experimental design used was a complete randomized block in a splitplot. The plots consisted of three residual heights $(70,90$ and $110 \mathrm{~cm})$, and the subplots were four seasons (fall, winter, spring and summer) with four replicates. There was no $(\mathrm{P}>0.05)$ interaction between season and residual heights for agronomic characteristics. However, these features were influenced by the cutting season, with no significant effect $(\mathrm{P}>0.05)$ on residual height. Significant effects $(\mathrm{P}<0.05)$ were observed for dry matter, mineral matter, acid detergent fiber and ether extract in cutting seasons and residual height. Gliricidia sepium can be cut at a residual height of $70 \mathrm{~cm}$, with better agronomic characteristics and chemical composition occurring in the fall.
\end{abstract}

Key words: Cutting management, harvest time, legumes, nutritional value, semiarid.

\section{Introduction}

Choosing adapted and resistant forage species for the Brazilian semiarid region is a major challenge for producers, as irregular rainfall is the greatest obstacle to food production in the region. This causes

Received May 17, 2016. Accepted February 20, 2017 Corresponding author: shirferreira@yahoo.com.br feedstock shortage during drought periods and increasing production costs due to the need of using supplements in diets (Ferreira et al., 2009; Silveira, 2011). Temperature and humidity can also influence forage availability throughout the year, even in crops that show high resistance to annual water deficits.

In this context Gliricidia sepium (Jacq.) Steud, a leguminous tree originating in Central America, 
represents an important commercial and economic alternative due to its adaptation to dry regions and multiple uses (Rangel et al., 2011). This species has a high nutritional value, fast growth, high regeneration capacity, and high potential for forage production (Hurtato et al., 2012).

The cutting intensity of forage affects regrowth, which is also influenced by the weather conditions at the time the cut is made. Forage production is seasonal in tropical regions, affecting both forage yield and quality (Costa et al., 2013). Forage quality decreases as the plant matures, which usually matches the beginning of the dry season, increasing fiber and lignin contents and reducing crude protein. Given the low availability of forage in pastures in the Brazilian semiarid region, especially during the dry season, it is extremely relevant to study G. sepium throughout the year to evaluate its potential and implement better management.

This study was conducted to evaluate the agronomic characteristics and chemical composition of G. sepium under different residual heights in four different seasons.

\section{Materials and methods}

The experiment was conducted in the Forage Sector of the Department of Animal Science at the Federal University of Ceará (UFC), Fortaleza, Ceará State. Fortaleza is located in the Coastal Zone, $21 \mathrm{~m}$ altitude, 343'02', S and $38^{\circ} 32^{\prime} 35^{\prime \prime}$ 'W. According to Köppen and Geiger (1928), the climate is $A w$, tropical rainy, with rains concentrated in the summer and an average annual rainfall of $800 \mathrm{~mm}$ distributed from January to April.

An area of $600 \mathrm{~m}^{2}$ was planted with 336 plants of $G$. sepium. The plantation was established in 2010 with approximately 3 -cm-diameter and 20 -cm-length stem sections spaced $1.0 \times 1.5 \mathrm{~m}$ apart. Soil chemical analysis was conducted at the Laboratory of Soils at the Federal University of Ceará (Table 1).

Table 1. Soil chemical characteristics of the experimental area.

\begin{tabular}{|c|c|c|c|c|c|c|c|}
\hline \multicolumn{8}{|c|}{$\mathrm{pH}$} \\
\hline $\mathrm{H}_{2} \mathrm{O}$ & $\mathrm{P}$ & K & $\mathrm{Ca}+\mathrm{Mg}$ & $\mathrm{Al}$ & $\mathrm{Ca}$ & $\mathrm{Mg}$ & $\mathrm{Na}$ \\
\hline \multicolumn{8}{|c|}{$-\mathrm{mg} / \mathrm{dm}^{-3}-$} \\
\hline 6,1 & 9 & 70 & 3,5 & 0 & 1,9 & 1,6 & 8 \\
\hline
\end{tabular}

Climatic data were gathered at the UFC's Weather Station, located approximately $600 \mathrm{~m}$ from the experimental site (Figures 1 and 2). A standardization cut was held on March 21, 2013 (the end of the summer solstice and the beginning of autumnal equinox), corresponding to the beginning of the rainy season. The soil was fertilized with $90 \mathrm{~kg} \mathrm{ha}^{-1}$ super phosphate $\left(\mathrm{P}_{2} \mathrm{O}_{5}\right)$ and $60 \mathrm{~kg} \mathrm{ha}^{-1}$ of potassium chloride $\left(\mathrm{K}_{2} \mathrm{O}\right)$ with a single dose.

Plants were harvested for evaluation on June 21 (the end of autumn and the beginning of winter), September 21 (the end of winter and the beginning of spring), December 21 (the end of spring and the beginning of the summer) in 2013, and March 21 (the end of the summer and the beginning of autumn) in 2014. In all cuts, seven eligible plants, identified with colored ribbons per plot and per treatment, were evaluated according to their residual heights (70, 90 and $110 \mathrm{~cm})$.

For growth analysis, the following nondestructive variables were measured: stem diameter at the ground level (STD), shoot diameter (SHD), number of shoots (NS) and plant growth (PG). For the stem and shoot diameter evaluation, a digital caliper was used measuring at a distance $5 \mathrm{~cm}$ from the ground and shoot base, respectively. Plant growth was measured from ground level to the highest branch using a graduated scale, and the residual height for each treatment was subtracted from this result. Leaf area index was calculated using a glass grid with known area which was placed over the leaves to count the number of squares contained inside the leaves borders. 
At the beginning of each season, plants were cut with pruning shears according to pre-established residual heights. Collected material was weighed to obtain total mass of fresh forage for each treatment. Branches and leaves up to $1 \mathrm{~cm}$ in diameter were separated, and composite samples of approximately $500 \mathrm{~g}$ were retained to determine the chemical composition. Samples were dried in a forced air circulation oven at $65^{\circ} \mathrm{C}$ for $72 \mathrm{~h}$ until achieving a constant weight. Dry samples were removed, weighed and ground in a Wiley knife mill with a 1-mm sieve and then stored in plastic containers.

Dry matter content was determined as well: crude protein $(\mathrm{CP})$ in nitrogen distillers using the Kjeldahl method; ether extract (EE) using the Goldfish method; mineral matter (MM) in a muffle furnace at $600{ }^{\circ} \mathrm{C}$; and neutral detergent fiber (NDF) and acid detergent fiber (ADF) using ANKOM equipment. Methods described in AOAC (1990) were used for the determination of DM, MM, CP and EE. NDF and ADF were determined according to Van Soest et al. (1991).

The experimental design was complete randomized blocks in a split-plot. Plots consisted of three residual heights (70, 90 and $110 \mathrm{~cm})$ and subplots of 4 seasons (fall, winter, spring and summer) with four replicates. The data of agronomic character- istics and chemical composition were submitted to analysis of variance (ANOVA). Means were compared by the Tukey test $(\mathrm{P}<0.05)$. Analysis was performed using the statistical software SAS version 9.0 (SAS Institute, 2002).

\section{Results and discussion}

There was no interaction $(\mathrm{P}>0.05)$ between cutting seasons and residual height for the agronomic characteristics of G. sepium. However, they were influenced by the cutting season (Table 2). Plant growth during autumn was approximately three times higher than in spring. This result was similar to that found by Lopes et al. (2000), who evaluated morphophysiological characteristics of Leucaena leucocephala in two seasons (dry and rainy) and found a higher plant growth during the rainy season. The lower plant growth observed in spring was due to the low rainfall occurring in October, November and early December in 2013 (Figure 2).

Stem and shoot diameter (STD and SHD) were higher $(\mathrm{P}<0.05)$ in the winter when compared to other cutting periods (Table 2 ). It is worth noting that the rainfall preceding this cut occurred in June and July with little variation in temperature (Figures 1 and 2). This condition certainly favored

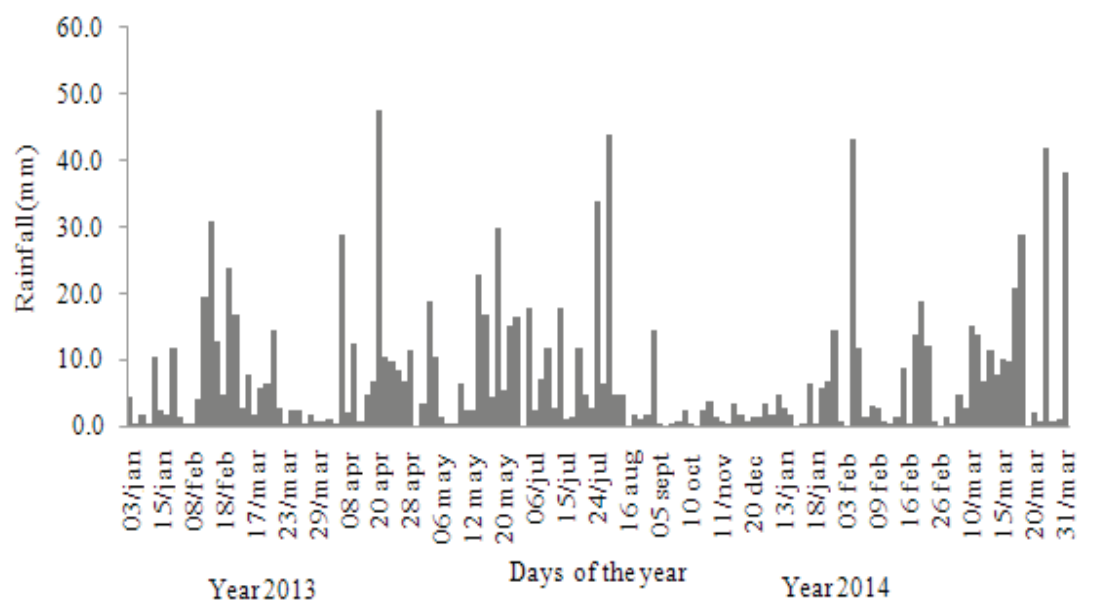

Figure 2. Rainfall recorded during the experiment in Fortaleza city, Ceará State. 
accumulation of reserves in plants, allowing for an increase in STD and SHD. STD and SHD was registered in September, 2013 at 6.85 and 2.70 $\mathrm{cm}$, respectively. These values were 2.5 and 3.4 times higher than those registered in the summer.

The number of shoots (NS) in the summer was higher than in other seasons. This must have occurred as a result of increased rainfall in January, February and March prior to the cut, as the summer is considerably rainy in this region, as shown in Figures 1 and 2. However, Perrando and Corder (2006), evaluating Acacia mearnsii in Rio Grande do Sul State Brazil, observed higher plant regrowth occurring during the winter and spring (September and December), seasons of less oscillation between temperature and precipitation, thus favoring growth. A higher NS occurred in the summer when the 4th cut was conducted, and an average of 31.33 shoots per branch were recorded. This number was lower than that found by Edvan et al. (2014) when managing G. sepium with a residual height of $90 \mathrm{~cm}$ and a cutting frequency of 90 days, when 42 shoots per branch were recorded during the summer.

It was observed that the leaf area index (LAI) was higher $(\mathrm{P}<0.05)$ in autumn. A higher rainfall in the previous months to the cut may have contributed positively to this result. Chaves et al. (2007) verified similar results assessing Eucalyptus grandis canopy, where the LAI was higher in the rainy season, presenting a quick plant recovery after the cut at the beginning of the rainy season. Precipitation is the main climatic variable influencing plant growth in Brazil, especially in

Table 2. Agronomic characteristics of Gliricidia sepium, plant growth (PG), stem diameter (STD), diameter of the shoots (SHD), number of shoots (NS), leaf area index (LAI), total mass of fresh forage (TMFF), and total mass of dry forage (TMDF) according to seasons and residual height.

\begin{tabular}{|c|c|c|c|c|c|c|}
\hline \multirow{2}{*}{ Variables } & \multicolumn{6}{|c|}{ Seasons } \\
\hline & Fall 2013 & Winter 2013 & Spring 2013 & Summer 2014 & & SD \\
\hline PG (m) & $0.81 \mathrm{a}$ & $0.38 b c$ & $0.26 \mathrm{c}$ & $0.46 b$ & & 0.23 \\
\hline $\mathrm{SD}(\mathrm{cm})$ & $2.06 \mathrm{c}$ & $6.85^{\mathrm{a}}$ & $4.10 \mathrm{~b}$ & $2.74 \mathrm{c}$ & & 2.11 \\
\hline $\mathrm{DS}(\mathrm{cm})$ & $0.83 b$ & $2.07^{\mathrm{a}}$ & $1.07 \mathrm{~b}$ & $0.68 b$ & & 0.37 \\
\hline NS & $22.83 \mathrm{c}$ & $23.83 b c$ & $25.16 b c$ & $31.33 \mathrm{a}$ & & 4.49 \\
\hline $\mathrm{LAI}\left(\mathrm{m}^{2}\right)$ & $1.13 \mathrm{a}$ & $0.19 \mathrm{c}$ & $0.72 b$ & $0.48 b c$ & & 0.39 \\
\hline TMFF (t.ha $\left.{ }^{-1}\right)$ & $13.13 \mathrm{a}$ & $5.86 \mathrm{~b}$ & $4.89 \mathrm{~b}$ & $7.96 \mathrm{~b}$ & & 3.67 \\
\hline \multirow[t]{3}{*}{$\operatorname{TMDF}\left(\mathrm{t} \mathrm{ha}^{-1}\right)$} & $3.49 \mathrm{a}$ & $1.65 b$ & $1.24 \mathrm{~b}$ & $1.94 \mathrm{~b}$ & & 0.98 \\
\hline & \multicolumn{6}{|c|}{ Residual Height } \\
\hline & $70 \mathrm{~cm}$ & $90 \mathrm{~cm}$ & $110 \mathrm{~cm}$ & & SD & \\
\hline PG (cm) & 0.46 & 0.53 & 0.44 & & 0.10 & \\
\hline $\mathrm{SD}(\mathrm{cm})$ & 3.66 & 4.07 & 4.09 & & 0.24 & \\
\hline $\mathrm{DS}(\mathrm{cm})$ & 1.17 & 1.17 & 1.14 & & 0.10 & \\
\hline NS & 23.12 & 26.43 & 27.81 & & 2.41 & \\
\hline $\mathrm{LAI}\left(\mathrm{m}^{2}\right)$ & 0.68 & 0.70 & 0.51 & & 0.10 & \\
\hline TMFF $\left(\right.$ t.ha $\left.^{-1}\right)$ & 8.16 & 7.83 & 7.89 & & 0.17 & \\
\hline $\operatorname{TMDF}\left(\mathrm{t} \cdot \mathrm{ha}^{-1}\right)$ & 2.20 & 2.11 & 1.92 & & 0.14 & \\
\hline
\end{tabular}

Means with different letters in the line significantly different $(\mathrm{P}<0.05)$ by Tukey test. SD: standard deviation. 
regions close to the equator, because temperature is nearly constant throughout the year, except in the extreme South.

The highest yield of total mass of fresh forage (TMFF) and total mass of dry forage (TMDF) was 13.13 and $3.49 \mathrm{t} \mathrm{ha}^{-1}$ (Table 2), respectively, and registered in autumn. Previous rainfall and an average of $12 \mathrm{~h}$ of sunlight per day may have contributed to these higher values. Gomez et al. (2002) stated that $G$. sepium is very demanding in terms of sunlight, as observed in this study that under ideal conditions of water supply and solar radiation, plants presented elevated yield for TMFF and TMDF.

Regarding the residual height, no significant differences were observed $(\mathrm{P}>0.05)$ for agronomic characteristics (Table 2). This result attests to the adaptation and resistance that plants present under different cutting management. It could also be noticed that residual heights of 70 to $110 \mathrm{~cm}$ provided higher growth for G. sepium. Edvan et al. (2014) stated that a residual height of $60 \mathrm{~cm}$ was not appropriate for this species. In relation to the chemical composition, an interaction $(\mathrm{P}<0.05)$ was observed between residual height and cutting season for NDF, CP and OM contents (Table 3). No interaction effect $(\mathrm{P}>0.05)$ was verified for $\mathrm{DM}, \mathrm{MM}, \mathrm{ADF}$ and $\mathrm{EE}$ contents.

Higher levels of NDF were registered in the winter and spring for all residual heights (70, 90 and $110 \mathrm{~cm}$ ). According to Duarte (2012), NDF concentration is the parameter that seems to be most influenced by the low amount of water in the soil, decreasing the amount of carbon incorporated into the cell wall and increasing fiber content. The high NDF content suggests a reduction in the nutritional value of the forage for ruminants, indicating that G. sepium would probably have its nutritional value reduced during this season.

In contrast, lower NDF values were observed in the fall for a residual height of $70 \mathrm{~cm}$ and in the summer for residual heights of 70 and $90 \mathrm{~cm}$. These heights

Table 3. Mean values of neutral detergent fiber (NDF), crude protein (CP) and organic matter (OM) in Gliricidia sepium at different times in relation to residual height.

\begin{tabular}{cccccc}
\hline \multirow{2}{*}{ Residual height } & \multicolumn{5}{c}{ Seasons } \\
\cline { 2 - 5 } & Fall 2013 & Winter 2013 & Spring 2013 & $\begin{array}{c}\text { Summer } \\
2014\end{array}$ & SD \\
\hline NDF (\% DM) & & & & & \\
$70 \mathrm{~cm}$ & $54.82 \mathrm{bB}$ & $63.79 \mathrm{aA}$ & $63.44 \mathrm{aA}$ & $54.35 \mathrm{bC}$ & 5.21 \\
$90 \mathrm{~cm}$ & $60.94 \mathrm{aA}$ & $64.08 \mathrm{aA}$ & $64.65 \mathrm{aA}$ & $60.35 \mathrm{aB}$ & 2.17 \\
$110 \mathrm{~cm}$ & $62.23 \mathrm{aA}$ & $62.32 \mathrm{aA}$ & $64.38 \mathrm{aA}$ & $65.33 \mathrm{aA}$ & 1.53 \\
CP $(\% \mathrm{DM})$ & & & & \\
$70 \mathrm{~cm}$ & $20.66 \mathrm{aA}$ & $22.76 \mathrm{aA}$ & $18.65 \mathrm{aA}$ & $22.31 \mathrm{aA}$ & 2.12 \\
$90 \mathrm{~cm}$ & $16.23 \mathrm{bA}$ & $21.40 \mathrm{aA}$ & $20.63 \mathrm{aA}$ & $22.92 \mathrm{aA}$ & 2.87 \\
$110 \mathrm{~cm}$ & $20.34 \mathrm{aA}$ & $21.81 \mathrm{aA}$ & $18.54 \mathrm{bA}$ & $24.73 \mathrm{aA}$ & 2.61 \\
OM $(\% \mathrm{DM})$ & & & & \\
$70 \mathrm{~cm}$ & $80.30 \mathrm{bB}$ & $84.86 \mathrm{aA}$ & $81.71 \mathrm{bA}$ & $81.26 \mathrm{bA}$ & 2.34 \\
$90 \mathrm{~cm}$ & $84.38 \mathrm{aA}$ & $85.42 \mathrm{aA}$ & $81.47 \mathrm{abA}$ & $80.36 \mathrm{bA}$ & 2.38 \\
$110 \mathrm{~cm}$ & $84.08 \mathrm{aA}$ & $84.30 \mathrm{aA}$ & $82.47 \mathrm{aA}$ & $81.59 \mathrm{aB}$ & 1.30 \\
\hline
\end{tabular}

Means with different lowercase letters in line (residual height $\mathrm{x}$ seasons) and different capital letters in column (seasons $\mathrm{x}$ residual height) are different $(\mathrm{P}<0.05)$ by Tukey test. SD: standard deviation. 
were influenced by rainfall during the seasons, but this was not observed for those managed at a residual height of $110 \mathrm{~cm}$, probably because these plants retained major supporting structures.

Higher levels of CP were registered in winter and summer for all residual heights (70, 90 and $110 \mathrm{~cm}$ ). This was mainly due to well-distributed rainfall in the previous months little variation (Figure 1), which may have favored a higher accumulation of cellular content in the plants. It is worth mentioning that values for $\mathrm{CP}$ in this study for plants managed at $70 \mathrm{~cm}$ residual height, even with minimal rainfall during a season, for example in December 2013, averaged 18\%, according to Van Soest (1994), this value is higher than those suitable for ruminants needs.

Higher levels of $\mathrm{OM}$ were registered $(\mathrm{P}<0.05)$ in the winter for all residual heights (70, 90 and $110 \mathrm{~cm}$ ) (Table 3). This result may be related to the higher DM content and lower MM content observed in this season (Table 4), as OM content is proportional to the levels of DM and MM. A significant effect was observed $(\mathrm{P}<0.05)$ for $\mathrm{DM}$, $\mathrm{MM}, \mathrm{ADF}$ and EE for cutting seasons (Table 4). Higher DM content was observed for plants submitted to cut in the winter, which may be an effect of high rainfall and temperature indices in

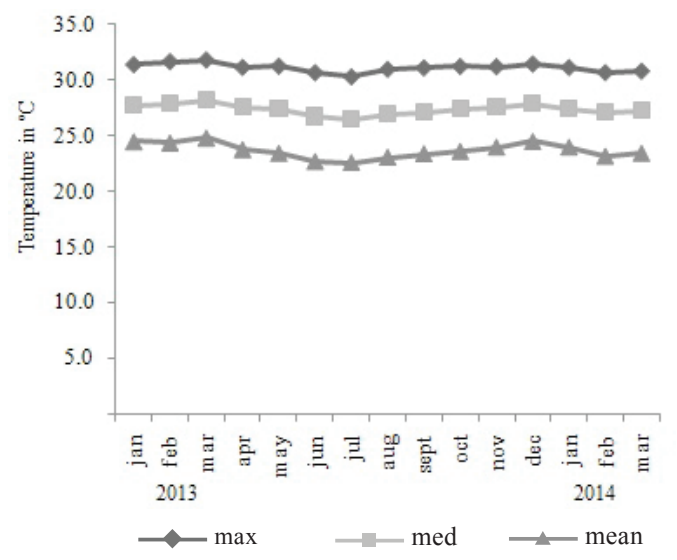

Figure 1. Minimum, average and maximum temperature (monthly average) during the experimental period (20132014) in Fortaleza city, Ceará State. previous months. Plants managed in the spring showed a higher percentage of MM, differing from the other seasons. Low rainfall registered in September and November 2013 may have affected concentrations of this nutrient in the plants.

According to Gris et al. (2008), minerals play an important role in the animal organism, being essential for production and maintenance. Mineral content may vary in plants according to the period of cut and their vegetative stage. Higher ADF content was verified in autumn and winter (Table 4). The EE content in the winter was higher than other cuts. Low rainfall recorded before this cut in June, July and August 2013 may have promoted an increase in the percentage of EE.

No significant differences were observed $(\mathrm{P}>0.05)$ for the percentages of DM and $\mathrm{ADF}$ for residual heights of 70, 90 and $110 \mathrm{~cm}$ (Table 4). However, it was observed that the residual height of $70 \mathrm{~cm}$ presented a higher percentage of MM followed by 90 and $110 \mathrm{~cm}$.

For percentages of EE, the highest value was obtained on a residual height of $110 \mathrm{~cm}$, probably related to the greater height, which may have contributed to an increase in concentration of reserves in the plant, consequently affecting this component. According to Bakke et al. (2010), differences in the chemical composition of Leguminosae are closely related to the genetic characteristics of each plant, such as differential absorption of nutrients and conversion of photosynthetic metabolites, climate and soil conditions, or even different stages of leaf maturity.

In Northeast Brazil, where seasons are not well defined, differences for the variables evaluated in the seasons were mainly affected by variations in precipitation, as the temperature is almost constant during the year (Figure 1). This region is characterized by two distinct periods where $G$. sepium. presented differences in development and composition, a rainy season (summer and fall) with fast growth and high nutritional value, and a 
Table 4. Mean values of dry matter (DM) mineral matter (MM) acid detergent fiber (ADF) and ether extract (EE) in Gliricidia sepium according to seasons and residual height.

\begin{tabular}{lccccc}
\hline \multirow{2}{*}{ Variables } & \multicolumn{5}{c}{ Seasons } \\
\cline { 2 - 6 } & Fall 2013 & Winter 2013 & Spring 2013 & Summer 2014 & SD \\
\hline DM (\%) & $28.18 \mathrm{~b}$ & $30.92^{\mathrm{a}}$ & $25.40 \mathrm{c}$ & $24.54 \mathrm{c}$ & 2.89 \\
MM (\%) & $6.28 \mathrm{~b}$ & $6.57 \mathrm{~b}$ & $8.41 \mathrm{a}$ & $6.19 \mathrm{~b}$ & 1.04 \\
ADF (\%) & $43.90 \mathrm{a}$ & $42.98^{\mathrm{a}}$ & $42.47 \mathrm{~b}$ & $40.60 \mathrm{~b}$ & 1.39 \\
EE (\%) & $3.51 \mathrm{c}$ & $6.16^{\mathrm{a}}$ & $4.55 \mathrm{~b}$ & $5.19 \mathrm{ab}$ & 1.11 \\
\cline { 2 - 6 } & & Residual Height & & \\
\cline { 2 - 6 } & $70 \mathrm{~cm}$ & $90 \mathrm{~cm}$ & $110 \mathrm{~cm}$ & & 0.18 \\
\cline { 2 - 6 } DM (\%) & 27.47 & 27.11 & 27.20 & & 0.58 \\
MM (\%) & $7.49 \mathrm{a}$ & $6.78 \mathrm{ab}$ & $6.32 \mathrm{~b}$ & & 1.66 \\
ADF (\%) & 40.56 & 43.43 & 43.47 & & 0.66 \\
\hline EE (\%) & $4.49 \mathrm{~b}$ & $4.45 \mathrm{~b}$ & $5.62 \mathrm{a}$ & & \\
\hline
\end{tabular}

Means with different lowercase letters in line are significantly different $(\mathrm{P}<0.05)$ by Tukey test. SD: standard deviation.

dry season (winter and spring) with slow growth and low nutritional value, where plant growth is defined by the total precipitation.

Gliricidia sepium should be managed with a residual height of $70 \mathrm{~cm}$. The season where G. sepium showed higher dry matter production, plant growth and better chemical composition was autumn.

\section{Acknowledgements}

Thanks to the Higher Level Personnel Improvement Commission (CAPES) for providing a scholarship to carry out this experiment and to the Federal University of Ceará for providing the facilities where this work was conducted.

\section{Resumen}

S.F. Silva, M.S. de S. Carneiro, R.L. Edvan, E.S. Pereira, L.B. de M. Neto, A.P. Pinto, y D. de A. Camilo. 2017. Características agronómicas y composición química de Gliricidia sepium cultivadas bajo diferentes alturas residuales en diferentes estaciones del año. Cien. Inv. Agr. 44(1): 35-42. Este estudio tuvo como objetivo evaluar las características agronómicas y la composición química de Gliricidia sepium manejado con diferentes residuos en diferentes estaciones del año. El diseño estadístico fue de bloques al azar en parcelas divididas. Los residuos incluyeron tres diferentes alturas $(70,90 \mathrm{y} 110 \mathrm{~cm})$ y las subparcelas incluyeron cuatro estaciones del año (otoño, invierno, primavera y verano), con cuatro repeticiones. No hubo interacción $(\mathrm{P}>0.05)$ entre la estación y la altura de residuo en las características agronómicas de G. sepium. Sin embargo, estas características fueron influenciadas por el tiempo de corte. Efectos significativos $(\mathrm{P}<0.05)$ se obtuvieron para la materia seca promedio, cenizas, fibra detergente ácido y extracto etéreo. G. sepium puede ser manejado dentro de la altura residual de $70 \mathrm{~cm}$, con mejores características agronómicas y composición química en la estación de otoño.

Palabras clave: Legumbres, manejo de corte, semiárido, tiempo de corte, valor nutritivo. 


\section{References}

AOAC-Official Methods of Analysis. 1990. 15 $5^{\text {th }}$ edition. Association of Official Analytical Chemists, Inc. Arlington, Virginia, USA. 771 pp.

Bakke, I.A., J.F. Souto, P.C. Souto, and O.A. Bakke. 2010. Características de crescimento e valor forrageiro da Moringa (Moringa oleifera lam.) submetida a diferentes adubos orgânicos e intervalos de corte. Engenharia Ambiental-Espírito Santo do Pinhal 7:133-144.

Chaves, R.A., M.G.F. Reis, G.G. Reis, J.E.M. Pezzopane, A. Xavier, and M.A. Monte. 2007. Dinâmica de cobertura de dossel de povoamento de clone de Eucalyptus grandis w. hill ex-maiden submetidos a desrama artificial a desbaste. Revista Árvore 31:989-998.

Costa, N.L., J.P.G. Soares, C.R. Townsend, R.G.A. Pereira, J.A. Magalhaes, and B.H.N. Rodrigues. 2013. Efeito de regimes de cortes sobre a produtividade e composição química do guandu ( $\mathrm{Ca}$ janus cajan) em Porto Velho, Rondônia. Pubvet, $7(2): 1491$.

Duarte, A.L.M. 2012. Efeito da água sobre o crescimento e o valor nutritivo das plantas forrageiras. Revista Pesquisa e Tecnologia 9:1-6.

Edvan, R.L., M.S. de S.Carneiro, J.A. Magalhães, D.R. Albuquerque, M.S.M. Silva, L.R. Bezerra, R. L.Oliveira, and E.M. Santos. 2014. The forage yield of Gliricidia sepium during the rainy and dry seasons following pruning management in Brazil. Cien. Inv. Agr. 41:309-316.

Ferreira, M.A., F.V. Bispo, and M. Azevedo. 2009. Estratégias na suplementação de vacas leiteiras no semiárido do Brasil. Revista Brasileira de Zootecnia 38:322-329.

Gómez, M.E., L. Rodríguez, E. Murgueitio, C.I. Ríos, M.R. Méndez, C.H. Molina, C.H. Molina, E. Molina, and J.P. Molina. 2002. Árboles $\mathrm{y}$ arbustos forrajeros utilizados en alimentación animal como fuente protéica. 3th ed. Centro para la Investigación en Sistemas Sostenibles de Producción Agropecuaria, Cali, Colombia.

Gris, C.F., P.M. Rezende, E.A. Carvalho, E.P. Botrel, A.R. Evangelista, and M.J.B. Andrade. 2008.
Época de corte e cultivares na composição mineral de feno de soja [Glicine max (1.) merril]. Ciência Agrotécnica 32:413-419.

Hurtato, D.I., S. Nocua, and W. Narváez-Solarte. 2012. Valor nutricional de la morera (Morus sp.), matarratón (Gliricidia sepium), pasto india (Panicum máximum) y arboloco (Montanoa quadrangularis) en la alimentación de cuyes (Cavia porcellus). Revista de Veterinária e Zootecnia 6:56-65.

Köppen, W., and R. Geiger. 1928. Klimate der Erde. Gotha: Verlag Justus Perthes. Wall-map $150 \mathrm{~cm}$ $\mathrm{x}-200 \mathrm{~cm}$.

Lopes, W.B., D.S. Silva, E.C. Pimenta Filho, J.L. Queiroz Filho, J.P. Silva, J.L.R. Sarmento, and R.L. Silva. 2000. Avaliação morfofisiológica da leucena (Leucaena leucocephala) submetida a dois espaçamentos em duas épocas. Revista Científica de Produção Animal 2:131-140.

Perrando, E.R., and M.P.M. Corder. 2006. Rebrota de cepas de Acacia mearnsii em diferentes idades, épocas do ano e alturas de corte. Pesquisa Agropecuária Brasileira 41:555-562.

Rangel, J.H.A., E.N. Muniz, C.O. Sá, and J.L. Sá. 2011. Implantação e manejo de legumineira com gliricídia (Gliricidia sepium). Circular Técnica 35, Aracuju, Brasil.

SAS Institute Inc. 2002. Statistical Analysis System user's guide. Version 9.0. Cary, Statistical Analysis System Institute.

Silveira, M.T. 2011. Caracterização biométrica e físico-química das sementes e amêndoas da faveleira (Cnidosculus phyllacanthus (mart.) pax. et k. hoffm.) com e sem espinhos. Revista Verde de Agroecologia e Desenvolvimento Sustentável 6:41-45.

Van Soest, P.J., J.B. Robert, and B.A. Lewis.1991. Methods for dietary fiber, neutral detergent fiber, and nonstarch polysaccharides in relation to animal nutrition. Journal of Dairy Science 74:3583-3597.

Van Soest, P.J. 1994. Nutritional ecology of the ruminant. $2^{\text {th }}$ Ed. Cornell University Press, New York, NY. 